\title{
Analysis of Panic Buying Behavior from Fear of Covid- 19 and Citizen Trust
}

\author{
Lusy Asa Akhrani ${ }^{1}$, Ilmi Durotun Nasiha ${ }^{2}$, Amira Octaviani ${ }^{3}$ \\ \{lusyasa@ub.ac.id $\left.{ }^{1}\right\}$ \\ Psychology Department, Universitas Brawijaya, Indonesia ${ }^{1,2,3}$
}

\begin{abstract}
Early in 2020 China, Japan, and dozens of other countries were busy with a terrible and deadly disease outbreak, Novel Coronavirus Diseases (COVID-19). Then, the spread of this virus is very concerned about it because of its very rapid spread through air media or fluids from the respiratory tract. This phenomenon has a significant impact on life globally. Anxiety, panic, and public fear of the virus create a new lifestyle that must be controlled by oneself. The health, economic, educational, political, social, and psychological impacts are felt by all people in all countries. The obvious psychological impact is panic buying, self-control, trust in the government, and fear of COVID19. This study aims to determine the role of fear of COVID19 and citizen trust to panic buying behavior. The research conducted using quantitative correlation methods, involving research respondents with a minimum sample of 536 people. The character of the research response was at least 18 years old and affected by Covid19. Data processing using Multiple regression with the help of SPSS software. The research result shows that panic buying build from fear of COVID and citizen trust. Both fears of covid-17 and citizen trust have a simultaneous role in panic buying. However, in the partial role only fear of covid which have a role to panic buying, while citizen trust has not role to panic buying.
\end{abstract}

Keywords: Citizen trust, fear of covid-19, panic buying

\section{Introduction}

According to the World Health Organization (WHO), Corona Virus is a virus that attacks the respiratory system which is often called COVID-19. As of October 30th, 2020 the number of confirmed cases of patients exposed to COVID-19 has reached 44,592,789. A total of 1,175,553 confirmed patients died from 219 countries or regions affected by COVID-19 [40]. According to the distribution map data issued by the Ministry of Health of the Republic of Indonesia (Kemenkes RI), on October 30th, 2020 there were 406,945 confirmed cases, and 13,782 patients were declared dead in 34 provinces in Indonesia.

The COVID-19 pandemic experienced by the world community has an impact on the instability of life. Indonesia as a country that is affected by aspects such as economy, politics, education, social, sports, and religion as well as tourism is also affected. The impact is quite large on the economy, for example, a pandemic can trigger serious disruption of global food supplies. According to Shou, Xiong \& Shen [33], supply disruptions can cause by various reasons, such as natural disasters, labor strikes, terrorist attacks, and changes in government regulations, etc. The reporting of the first case in Indonesia appeared, many people invaded various kinds of staple goods. The number of supplies of masks and hand sanitizers in several 
shops and pharmacies is getting scarce [1]. The Indonesian Retail Entrepreneurs Association (Aprindo) stated that there had been a surge in visitors of around 10 percent to 15 percent after the first COVID-19 news in Indonesia so that the stock of goods in several shops invaded by the public [1]. Lidyana [26] wrote that there was a surge in mask prices of up to $1400 \%$ due to the scarcity of goods with a high number of requests. All supermarkets in the Jakarta area were often attacked by residents, which resulted in almost all food products sold out. This disruption of supply occurs due to panic buying behavior in which many consumers buy products in large quantities to avoid possible shortages in the future in the face of crises such as COVID-19. According to Arafat, Kar, Marthoenis, Sharma, Apu, \& Kabir [3], the perception of scarcity (the effect of perceived scarcity) is closely related to the increase in panic buying behavior and hoarding behavior if scarcity occurs in urgent needs. This scarcity also creates feelings of insecurity and activates the desired mechanism to collect goods [10].

According to Lins and Aquino [27], Panic buying occurs when there are negative feelings such as fear, panic, and uncertain feelings that underlie a person is acting to buy goods excessively. This occurs in a crisis or disturbing event. Panic buying has also been associated with feelings of insecurity that are felt in the instability of certain situations [20]. COVID-19 leaves people feeling uncertain, people unsure when disasters will end, and what can control in the face of a pandemic, giving rise to a desire to control at least something that is needed during a crisis namely, by saving necessities by buying as much as possible [3]. Yuen, Wang, Ma, and Li [41] explain several psychological factors that influence panic buying, including perception, fear of the unknown, coping behavior or coping strategies, and social psychological factors. The perceptions referred to in these factors are divided into two, namely perceptions of threats and perceptions of scarcity. Besides, social-psychological factors are also divided into two, namely, social influence and social trust.

Fear is a form of emotion that is formed because of danger or threatening situations. The response to fear in individuals is in the form of fight-or-flight where the individual behaves in the direction of running away or fighting the threatening situation [30]. Fear is also closely related to anxiety [9]. Besides, fear of individuals is not only motivated by individual traits but also influenced by the existence of certain social and cultural relationships [14]. Several things trigger fear, including objects or situations, imagined events, dangers to the real environment, and things that are not certain. Situation uncertainty and lack of information cause fear in addition to other psychological and physical problems in some populations, especially people who are constantly involved in a place or event, for example in a place of war, a place of conflict or disaster, terrorism, and others [13].

This fear also occurred during the pandemic COVID-19 around the world, especially in Indonesia. COVID-19 has entered life and changed the fabric of society, and reversed human domination on earth. The fact is that COVID-19 is a very microscopic virus, and people don't know how to control it. COVID-19 is also difficult to predict, so people become afraid of something they don't know, namely COVID-19 (Freeland, 2020). Fear is one of the aspects that emerged during the COVID-19 pandemic. Fear of COVID-19 is an unpleasant emotion felt by an individual due to a threat or unusual event, for example, an epidemic of a disease outbreak. There is a fear of being infected, losing a job, losing loved ones, and various other sides of life when COVID-19 occurs around the world [31]. Research in Canada reports that a total of 1354 adults are worried and afraid of COVID-19 (Angus Reid Institute, 2020). Besides that, Germany also conveyed the same thing. That 1242 individuals feel very afraid of COVID-19. Another study from the United States shows that people are afraid of the spread of COVID-19 rather than the influenza virus that occurs seasonally [4]. Fear of COVID-19 is a fear of health conditions. Fear of specific health conditions has also occurred in several diseases including 
fear of breast cancer [7], Alzheimer's disease [12], dementia [23], and hypoglycemia [2]. When they have a specific fear, for example against COVID-19, the individual has a certain response. Changes regarding healthy living behavior in society make it better to understand that humans are susceptible to disease [15].

Sim, Chua, Vieta \& Fernandez [34] explain that panic buying occurs because of a conflict that lies behind the desire to survive with the uncertainty of the duration of the pandemic. The uncertainty of the situation eventually leads the individual to be afraid and to relieve this feeling, the individual buys goods in unusual quantities. Besides, panic buying calls a coping response to fear. Harper, Satchell, Fido, \& Latzman [18] also convey that fear of COVID-19 is perceived by society as a threat and motivates individuals to adopt preventive behaviors that facilitate their lives. Subsequent research on cases of the SARS virus in 2003 and Swine Flu in 2009 in Hong Kong explained that there is a role for fear and anxiety in triggering panic buying behavior [11]. When the SARS virus occurs, there is a social behavioral response, namely high anxiety [24] and panic buying [8]. However, when the Swine Flu pandemic occurred, as many as $64 \%$ of Hong Kong residents were doing their usual activities [22], and the level of fear or anxiety was relatively low. Fast et al. [11] explained that experience and preparedness to face a pandemic affect the panic response in society. Panic buying behavior during the COVID-19 pandemic occurred because of a psychological conflict in the community regarding a sense of security with the desire to live normally [6]. Also, the fear factor is closely related to feelings of insecurity [3],[21].

The pandemic COVID-19 that occurred in Indonesia has become the media spotlight both at home and abroad. The relevant information has spread rapidly on various social media, from fact stories to fake reports that create panic among recipients. According to Cheng [8] the unclear information received can affect panic for individuals, besides that the more news received will also make someone think about an epidemic and cause panic. The massive amount of information related to unpleasant things can cause a panic effect on the recipient which in turn triggers panic buying behavior [32]. Information such as the increasing number of spreads, the death of medical personnel, to the scarcity of medical devices that can hinder emergency health services for COVID-19 [35]. In addition to various confusing reports regarding the development of the pandemic, media reporting the unclear government's response to COVID19 can also cause a decrease in trust in the government. According to Wijaya [39] a factor in the occurrence of panic buying behavior, namely a lack of trust in government information and response to information developments that make consumers not get complete information.

Public trust in government is seen as important in ensuring compliance and concerted and coordinated efforts to manage and control the spread of disease. The high level of social trust which includes trust in society and the government will show that individuals will be more cooperative and consider not hoarding goods or panic buying [41]. This is also supported Mas'udi \& Winanti [28] which states that when a pandemic occurs, there is a dilemma between health and economic needs. A country that has limited resources will worsen the situation if there is no good social solidarity, low trust, and public obedience to the government so that individuals tend to take their actions.

The government's role in handling the COVID-19 cases that occurred in Indonesia has drawn various criticisms over speed, effectiveness, and resilience. Starting with the government's attitude that is considered not responsive in overcoming COVID-19 in Indonesia, the government even denied through some funny jokes that COVID-19 will not enter Indonesia due to the difficulty of licensing [19]. Also, the Minister of Health asked the public to just "enjoy" dealing with this fast-spreading virus. This makes the public astonished to respond to jokes that seem relatable [17]. Chairman of the Anti-Slander Society (MAFINDO) Septiaji Eko 
Nugroho regretted the government's position of continuing to provide uncertainty through denying statements. This uncertainty will provide an assessment of a situation that is overly accepted which also arises from the results of a reaction of concern so that individuals tend to find it difficult to make rational decisions [32]. As described on the page (CNN Indonesia, 2020) after the reporting of the first case on March 2, 2020, the government tends to be closed and is reluctant to open data about the distribution of COVID-19 cases because they don't want the public to panic. According to UGM Communications expert Kuskridho Ambardi, the government is also considered to have three obstacles in handling this COVID-19 case, namely unclear coordination, firmness of distribution data, and limited handling information [36]. The fragility of coordination, strategic transparency, and responsive communication to the government in managing information will slowly have an impact on weakening public trust (citizen trust) in the government [28].

Public trust defines as the belief and availability in taking action both for one's benefit and for the benefit of others based on the object of trust, identified based on the results of an assessment of ability, virtue, and integrity [25]. Citizen trust is also explained as a collective assessment of one group on another group that the group will act honestly, can fulfill its commitments, and will not harm other groups [29]. An open and responsive government is an enabling environment to strengthen trust between the government and society in both directions [29]. According to Grimmelikhuijsen \& Knies [16] citizen trust in government can be seen from three dimensions. Perceived Competence, citizens perceive the government as capable, effective, capable, and professional in carrying out their duties. Perceived Benevolence the extent to which a citizen views government organizations to care about the welfare of society and is motivated to act in the public interest. Perceived Integrity how society views government organizations to be sincere, able to tell the truth and to fulfill their promises.

Based on the results of previous research belonging to Yuen et al. [41] which reviewed the factors that cause panic buying through social networks, it found that social trust factors consist of two main aspects, namely trust in society and government. Trust in government makes it clear that the government plays an important role in providing relief and recovery, maintaining order and control, and disseminating information to the public during disease outbreaks. When social trust is high, individuals will be more cooperative and do not hoard goods. When the trust of the community itself and the government is low, these individuals will tend to act individually. A high level of social trust will indicate that individuals will be more afraid of other people buying more than their share, which triggers panic buying behavior.

Researchers conducted analyze the effect of fear of covid and citizen trust on panic buying behavior. Researchers hope that this research will be able to provide benefits as a reference and serve as material for evaluating the government and the Indonesian people in response to the pandemic.

\section{Method}

This research is a type of correlational quantitative research. According to Azwar [5], a quantitative approach is an approach that emphasizes data in the form of numbers processed through statistical methods in the analysis process. Correlational research aims to investigate interrelated variables with each other, to obtain information on the level of relationship that occurs in two or more variables. This study uses three variables, namely the first independent variable $\left(x_{1}\right)$ is fear of covid, the second independent variable $\left(x_{2}\right)$ is citizen trust and the 
dependent variable (y) is panic buying. This study aims to determine the role of fear of covid19 and citizen trust in the government on panic buying behavior during the COVID-19 pandemic.

\subsection{Respondents}

According to Azwar [5] population is a group of subjects that will be subject to generalization. The population is all research subjects who have characteristics and qualities that have determine to be studied and researched in research [37]. The sampling method in this study was to use a purposive sampling technique. The use of this technique was chosen based on the characteristics possessed by members in the population who can provide information as needed in this study, characteristics as Indonesian citizens, aged at least 18 years, affected by the COVID-19 pandemic both economically, socially, culturally, healthily, education, and others. The number of respondents in this study was 536 participants who had the suitability of the characteristics as respondents in this study.

\subsection{Instrument}

This study uses three types of scales with a Likert scale. Each instrument item that uses a Likert scale will have a choice of answers from very negative to very positive, and from these answers have their respective scores [37]. The scale used in this study, based on the existing variables, there are three scales to be used, namely the Panic Buying scale, Fear of Covid-19, and Citizen Trust.

\subsubsection{Panic buying scale}

The Panic Buying Scale is used to measure excessive shopping behavior that occurs when a person experience concerns about the scarcity of goods when faced with a crisis or threatening situation. This study uses Wijaya's [39] Panic Buying scale. A scale of 15 items consists of four factors that affect the items answered using a 4-point Likert scale ranging from strongly disagree to strongly agree.

\subsubsection{Fear scale of COVID-19}

The Fear of COVID-19 scale is used by researchers to measure the fear raised by the community during the COVID-19 pandemic. This scale has a Cronbach Alpha of 0.82 which consists of 7 favorable items, which means that it supports the dimensions or theory and is answered using a 4-point Likert scale ranging from strongly disagree to strongly agree. This scale was developed by Ahorsu et al. (2020) which has a positive correlation and concurrent validity with Motazeri's (2003) Hospital Anxiety and Depression Scale (HADS) and Ahmadzadeh's Perceived Vulnerability to Disease Scale (PVDS) (2013).

\subsubsection{Citizen trust scale}

The Citizen Trust scale used by researchers to measure people's trust in the government in the COVID-19 pandemic conditions using the Citizen Trust in Government Organization (CTGO) scale, developed by Grimmelikhuijsen and Knies [16] which has been adapted by Wahyudi, Milla, \& Muluk [38] in his latest research using theoretical references [25]. This scale 
has a Cronbach Alpha of 0.930 consisting of 12 items that answered using a 4-point Likert scale ranging from strongly disagree to strongly agree. At this scale, it consists of three dimensions, consisting of Perceived Competence - the perception of citizens that the government is capable, effective, capable, and professional in carrying out its duties, Perceived Benevolence - the perception of citizens who view government organizations to care about the welfare of society and are motivated to act for the public interest, Perceived Integrity - society's perception of a government organization to be sincere, able to tell the truth and to fulfill its promises.

Based on Table 1, it is known that the three measuring instruments are in the high-reliability category, with the Citizen Trust Scale, the Cronbach's Alpha value is 0.949, the fear of covid is 0.82, and the Panic Buying Scale has a Cronbach's Alpha value of 0.945.

Table 1. Reliability

\begin{tabular}{lll}
\hline Variable & Reliability & Item \\
\hline Citizen Trust & 0.949 & 12 \\
Fear of Covid-19 & 0.82 & 7 \\
Panic Buying & 0.945 & 15 \\
\hline
\end{tabular}

\subsection{Data analysis}

This study aims to analyze the simultaneous and partial role of fear of covid-19 and citizen trust in panic buying using multiple linear regression with the help of SPSS software.

\section{Results and Discussion}

This study was analyzed through two tests, namely assumption testing and hypothesis testing. The results showed that there was a partial and simultaneous role between fear of covid and citizen trust in panic buying.

\subsection{Classic assumption test}

\subsubsection{Normality test}

The normality test was carried out by researchers to determine whether or not a data distribution was normal in the study using a simple regression analysis. The normality test was tested using the Kolmogorov-Smirnov (K-S) statistical test with the following values.

Based on Table 2, it is known that the asym value. Sig (2-tailed) of 0.070 , which means greater than 0.05 , it can be concluded that the normality test shows that the data is normally distributed. Also, data normality can be seen from Figure 1 which shows the data is normally distributed because it follows a diagonal line. 
Table 2. One-sample kolmogorov-smirnov test

\begin{tabular}{cll}
\hline \multicolumn{1}{c}{$\mathrm{N}$} & & 536 \\
\hline Normal Parameters & Mean & .0000000 \\
& Std. Deviation & 9.48612537 \\
Most Extreme Differences & Absolute & .037 \\
& Positive & .037 \\
& Negative & -.033 \\
Test Statistic & & .037 \\
Asymp. Sig. (2-tailed) & & $.070^{\mathrm{c}}$ \\
\hline
\end{tabular}

a. Test distribution is normal.

b. Calculated from data.

c. Lilliefors significance correction.

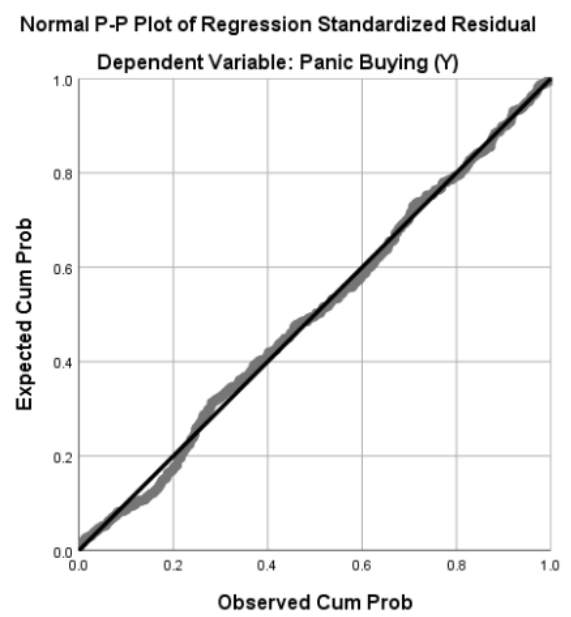

Fig. 1. Normality distribution

\subsubsection{Linearity test}

A linearity test was conducted to determine whether the data from this study, each variable can be linearly related following a straight line or not [37]. The linearity test results are shown by looking at the Deviation from Linearity value and the linearity value. The linearity test results are said to have a linear relationship if it is above the significance level of $<0.05$ (less than 0.05). The results of the data in Table 3 show a Linearity value of $0.000<0.05$, it can conclude that there is a significant linear relationship between the independent variable and the dependent variable.

Table 3. Linearity table

\begin{tabular}{ll}
\hline Variable & Test \\
\hline Fear of covid* & Linearity \\
Citizen Trust* Panic \\
Buying
\end{tabular}




\subsubsection{Multicollinearity test}

Based on Table 4, it is known that there are no symptoms of multicollinearity. Both fears of covid and citizen have a tolerance value of more than 0.100 and a VIF value of less than ten so that it can conclude that there are no symptoms of multicollinearity in the two independent variables.

Table 4. Multicollinearity test

\begin{tabular}{|c|c|c|}
\hline \multirow[b]{2}{*}{ Model } & \multicolumn{2}{|c|}{ Collinearity Statistics } \\
\hline & Tolerance & VIF \\
\hline \multicolumn{3}{|l|}{ (Constant) } \\
\hline Fear of Covid (X1) & .993 & 1.007 \\
\hline Citizen Trust (X2) & .993 & 1.007 \\
\hline
\end{tabular}

a. Dependent variable: panic buying (Y)

\subsubsection{Heteroscedasticity test}

Based on Figure 2, it shows that there are no symptoms of heteroscedasticity because the dots do not show a clear pattern such as not wavy, not widening, or not narrowing (Ghazali, 2011). The dots spread above and below the 0 on the $\mathrm{Y}$-axis.

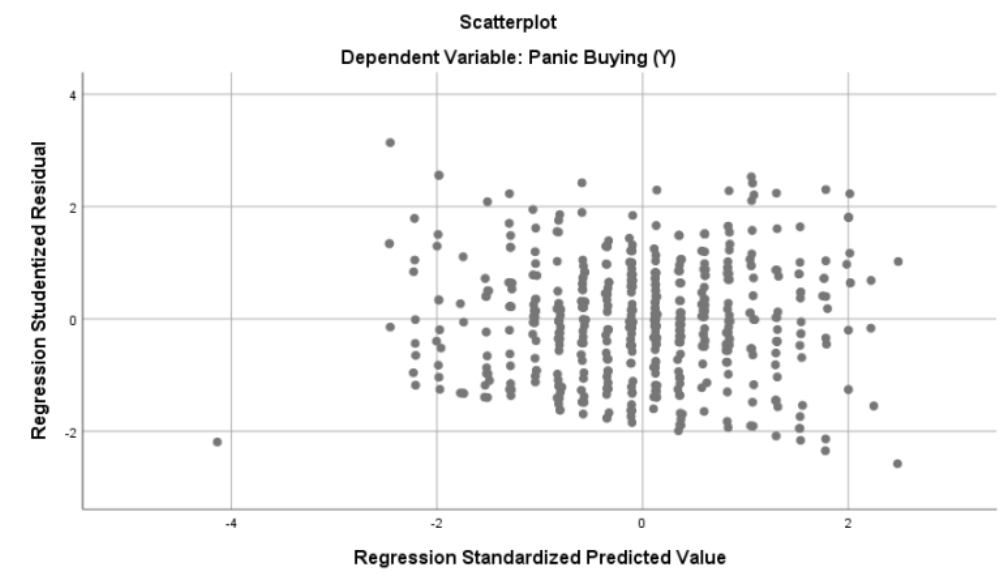

Fig. 2. Heterokedastisity

\subsection{Hypothesis test}

\subsubsection{Simultaneous role between fear of covid and citizen trust to panic buying}

The first hypothesis of this study aims to prove the simultaneous role of fear of covid and citizen trust in panic buying. The results of this study indicate that there is a role simultaneously 
between fear of covid and citizen trust in panic buying, this can be seen from the results of the $\mathrm{f}$ test. Multiple linear regression by looking at the simultaneous role based on the F test, namely the meaning of the role of variable $\mathrm{X}$ together with variable $\mathrm{Y}$ occurs when the significance value is less than 0.05. Based on the Table 5, it can conclude that fear of covid and citizen trust together play a role in panic buying by looking at the significance value of less than $0.05(0.000)$. The role size has seen from the R square value, namely 0.095 or $9.5 \%$.

Table 5. Simultanous role

\begin{tabular}{lcc}
\hline Model & R & R Square \\
\hline 1 & $.308^{\text {a }}$ & .095 \\
\hline a. Predictors: (constant), Citizen trust (X2), Fear of covid (X1) \\
b. Dependent variable: Panic buying (Y)
\end{tabular}

\subsection{2 t-test}

The partial role of each independent variable on the dependent variable through the t-test by looking at the significance value shown in Table 6 . it is seen that the significance value of the fear of the covid variable is 0.00 , while citizen trust has a value of 0.94 . It can conclude that partially only the fear of covid variable has a partial role in panic buying, while citizen's trust does not partially play a role in panic buying.

Table 6. t-test

\begin{tabular}{lll}
\hline \multicolumn{1}{c}{ Model } & Sig. \\
\hline 1 & (Constant) & .000 \\
& Fear of Covid (X1) & .000 \\
& Citizen Trust (X2) & .940 \\
\hline
\end{tabular}

a. Dependent variable: Panic buying (Y)

\subsection{Discussion}

This study aims to determine the simultaneous and partial between fear of COVID-19 and citizen trust in panic buying behavior during the COVID-19 pandemic in Indonesia. This study involved 536 respondents who were Indonesian citizens (WNI) who were at least 18 years old and were affected by the pandemic both socially, economically, educationally, and others.

The results of this study indicate that there is a simultaneous role between fear of COVID19 and citizen trust in panic buying behavior during the COVID-19 pandemic in Indonesia with significant results. Referring to Shadiqi et al. [32] which explains the psychological factors in the occurrence of panic buying, that there are four things behind this behavior, namely consumer behavior, fear and anxiety, uncertainty, and media exposure. Panic buying behavior is a manifestation of fear and anxiety that occurs in individuals about threats. Jinqiu and Wilson et al explain that this behavior is a survival mechanism or instinct of individuals that makes people afraid of death, which they do to defend themselves.

The pandemic COVID-19 in Indonesia has triggered social behavioral responses such as anxiety and fear. The fear of this with the public and the government that is not ready yet has an impact on panic buying behavior. The fear that occurs in the wider community causes psychological conflict so that there is a sense of being safe with the desire to survive normally. 
Fear is closely related to perceived security during the COVID-19 pandemic [3],[21]. A pandemic outbreak is considered a worrying threat, triggering feelings of anxiety and fear about the future, and one reason is the uncertainty of whether there will be enough food and supplies during this period. Panic buying can be a response to perceptions of a lack of control regarding the future and social demands [34], and this sense of loss of control has a major impact on stress levels. In this sense, people can deliberately engage in certain types of buying behavior as a reaction to emotional distress. Therefore, buying more than usual can be seen as a way to deal with feelings of uncertainty, and as an act of self-defense. High levels of anxiety or fear also indicate that individuals will be more prone to feeling insecure and behave to reduce their anxiety and fear resulting in excessive buying and hoarding behavior. Meanwhile, if individuals have a low level of anxiety or fear, they will be calmer to act and be more cooperative in dealing with the COVID-19 pandemic.

The fear of COVID-19 in society during this pandemic has a small role in panic buying behavior. Fear of COVID-19 explains the effect of $13 \%$ on panic buying behavior during the pandemic period in Indonesia, this is because many factors influence individuals to take panic buying actions or behavior. Shadiqi et al. [32] explained that in their research, some other variables and theories can explain factors that can increase panic buying behavior in a pandemic/crisis that is not explained in this study. Factors such as consumer behavior, media exposure, uncertainty, and social cognitive theory can explain the dynamics of panic buying behavior. Besides, Yuen et al. [41] also explain several factors that can increase panic buying behavior during a pandemic, including individual perceptions of health or other events that can trigger panic buying behavior, perceived threats and rarities, uncertainty, coping behavior, and psychological factors. social influences such as social influence and social trust. Naeem (2020) also explained in his research that panic over COVID-19 that triggers panic buying is grouped with factors from negative to positive, including ignorance, paranoia, sadness, fear of transmission of viruses, government blaming, relating to past pandemics, dissemination of information, calm in the face of crises, compliance, optimism, and health consciousness.

Other factors that influence other panic buying behavior are explained in proprietary research [39] which discusses the factors that shape panic buying behavior due to COVID-19 in Indonesia. This research was conducted using an exploratory study of several people who behave panic buying in areas affected by COVID-19. The first factor is information on the scarcity of an item or a diminishing stock in the market, lack of clarity on the availability of goods and food security, lack of accurate and valid information received by the public which results in panic. Second, panic buying behavior is defined as a form of protection for family members by fulfilling their daily needs to avoid a lack of supply of foodstuffs, medical devices, and also medicines. Third, includes the influence of other people's behavior and the condition of the shopping center. Finally, the factor of concern for restricting access is a form of security and tranquility. This factor occurs as a form of avoiding the risk of uncertainty about when this outbreak will end and also as a way to prevent a decrease in immunity due to not meeting daily needs. The explanation of other factors or variables above assumes that the fear of COVID-19 in the community in causing panic buying behavior during the COVID-19 pandemic in Indonesia is a small part of other things that can explain or influence the occurrence of panic buying behavior. 


\section{Conclusion}

The study of 536 Indonesian citizens affected by the Covid-19 pandemic shows that simultaneously fear of covid and citizen trust plays a role in panic buying. Meanwhile, partially citizen trust is not enough to encourage panic buying behavior, but fear of covid has a role in panic buying behavior.

\section{References}

[1] Ananda, A. (2020, Maret 3). Aksi Borong Sembako, Cuma Efek Kejut Virus Corona di RI. Retrieved Juli 2020, from CNN Indonesia: https://www.cnnindonesia.com/ekonomi/20200303063353-92479968/aksi-borong-sembako-cuma-efek-kejut-virus-corona-di-ri

[2] Anarte Ortiz, M., Caballero, F., Ruiz de Adana, M., Rondan, R., Carreira, M., Dominguez-Lopez, M., et al. (2011). Development of a new fear of hypoglycemia scale: FH-15. Psychological Assessment, 23(2), 398-405. doi: 10.1037/a0021927.

[3] Arafat, S. Y., Kar, S. K., Marthoenis, Sharma, Apu, E. H., \& Kabir, R. (2020). Psychological underpinning of panic buying during pandemic COVID-19. Psychiatry Research, Vol. 289. doi: 10.1016/j.psychres.2020.113061.

[4] Aubrey, A. (2020, 4 Februari). Poll: Most Americans Say U.S 'Doing Enough' to Prevent Coronavirus Spread. Dipetik Juli 2020, dari npr.org: https://www.npr.org/sections/healthshots/2020/02/04/802387025/poll-most-americans-say-u-s-doing-enough-to-prevent-coronavirusspread

[5] Azwar, S. (2015). Reliabilitas dan validitas. Yogyakarta: Pustaka Belajar.

[6] Bacon, A., \& Corr, P. (2020). Coronavirus (COVID-19) in the United Kingdom: A personality-based perspective on concerns and intention to self-isolate. British Journal of Health Psychology, 1-10, doi: 10.1111/bjhp. 12423 .

[7] Champion, V., Skinner, C., Menon, U., Rawl, S., Giesler, R., Monahan, P., et al. (2004). A breast cancer fear scale: Psychometric development. Journal of Health Psychology, 9(6), 753-762. doi: $10.1177 / 1359105304045383$.

[8] Cheng, C. (2004). To be paranoid is the standard? Panic responses to SARS outbreak in the Hongkong special administrative region. Asian Perspective, Vol. 28, No. 1, pp. 67-98. https://www.jstor.org/stable/pdf/42704444.

[9] Cisler, J. M., Olatunji, B. O., Feldner, M. T., \& Forsyth, J. P. (2010). Enotion regulaiton and the anxiety disorders: An integrative review. Journal of Psychopathology and Behavioral Assessment, Vol. 32(1), 68-82. doi: 10.1007/s10862-009-9161-1.

[10] Dholakia, U. (2020, Maret 21). Why Are We Panic Buying During the Coronavirus Pandemic? Retrieved juli 2020, from Psychology Today: https://www.psychologytoday.com/intl/blog/thescience-behind-behavior/202003/why-are-we-panic-buying-during-the-coronavirus-pandemic

[11] Fast, S., Gonzales, M., Wilson, J., \& Markuzon, N. (2015). Modelling the propagation of social response during a disease outbreak. Journal of The Royal Society Interface, 12(104). doi: 10.1098/rsif.2014.1105.

[12] French, S. L., Floyd, M., Wilkins, S., \& Osato, S. (2012). The Fear of Alzheimer's Disease Scale: A new measure designed to assess anticipatory dementia in older adults. International Journal Geriatric Psychiatry, doi: $10.1002 / \mathrm{gps} .2747$.

[13] Gallagher, B. (2008). Fear of the unknown. Safer Communities, Vol 7(3), 22-25. doi: $10.1108 / 17578043200800026$.

[14] Gill, M. J., \& Burrow, R. (2018). The function of fear in Institutional Maintenance: Feeling frightened as an essential ingredient in haute cuisine. Organization Studies, Vol. 39(4), 445-465. doi: $10.1177 / 0170840617709306$. 
[15] Ginting, H. (2020, 4 Juni). Perubahan Perilaku Sebagai Respon Terhadap Wabah COVID-19. Dipetik Juli 2020, dari himpsi.or.id: https://himpsi.or.id/blog/materi-edukasi-covid-195/post/perubahan-perilaku-sebagai-respon-terhadap-wabah-covid-19-127

[16] Grimmelikhuijsen, S., \& Knies, E. (2017). Validating a scale for citizen trust in government organizations. International Review of Administrative Sciences, 83(3), 583-601. doi: $10.1177 / 0020852315585950$

[17] Harison. (2020, Februari 11). Virus Corona, Indonesia, dan Lelucon yang Tak Lucu. Retrieved Juli 2020, from DetikNews: https://news.detik.com/kolom/d-4894401/virus-corona-indonesia-danlelucon-yang-tak-lucu

[18] Harper, C. A., Satchell, L. P., Fido, D., \& Latzman, R. D. (2020). Functional fear predicts public health compliance in the COVID-19 pandemic. International Journal of Mental Health and Addiction, doi: 10.1007/s11469-020-00281-5.

[19] Hartomo, G. (2020, februari 24). Kelakar Bahlil di Depan Hary Tanoe: Virus Korona Tak Masuk Indonesia Karena Izinnya Susah. Retrieved Juli 2020, from OkeFinance: https://economy.okezone.com/read/2020/02/24/320/2173155/kelakar-bahlil-di-depan-hary-tanoevirus-korona-tak-masuk-indonesia-karena-izinnya-susah

[20] Hendrix, C., \& Brinkman, H.-J. (2013). Food Insecurity and Conflict Dynamics: Causal Linkages and Complex Feedbacks. Stability: International Journal of Security \& Development, 2(2), 1-18. doi: http://dx.doi.org/10.5334/sta.bm

[21] Ippolito, M., Iozzo, P., Gregoretti, C., \& Cortegiani, A. (2020). Counterfeit filteriing facepiece respirators are posing an additional risk to healthcare workers during COVID-19 Pandemic. American Journal of Infection Control, 48(7). doi: 10.1016/j.ajic.2020.04.020.

[22] Lau, G. T., \& Lee, S. H. (1999, December). Consumers' Trust in a Brand and the Link to Brand Loyalty. Journal of Market-Focused Management, 4(4), 341-370. doi:10.1023/A:1009886520142

[23] Lee, M., \& Jung, D. (2020). Development and psychometric evaluation of a Fear of Dementia Scale for Community-Dwelling older Adults. Journal of Nursing Research, doi: 10.1097/JNR.0000000000000372.

[24] Leung, C. C., Lam, T. H., \& Cheng, K. K. (2020). Mass masking in the COVID-19 epidemic: People need guidance. The Lancet, 395(10228), 945. doi: 10.1016/S0140-6736(20)30520-1.

[25] Lewicki, R. J., Tomlinson, E. C., \& Gillespie, N. (2006, December). Models of Interpersonal Trust Development: Theoretical Approaches, Empirical Evidence, and Future Directions. Journal of Management, 32(6), 991-1022. doi:10.1177/0149206306294405

[26] Lidyana, V. (2020, Maret 03). Geger Corona di RI, Warga Borong Masker hingga Mi Instan. Retrieved Juli 2020, from DetikFinance: https://finance.detik.com/berita-ekonomi-bisnis/d4922702/geger-corona-di-ri-warga-borong-masker-hingga-mi-instan

[27] Lins, S., \& Aquino, S. (2020, September). Development and initial psychometric properties of a panic buying scale during COVID-19 pandemic. Heliyon, 6(9), 1-6. doi: 10.1016/j.heliyon. 2020.e04746

[28] Mas'udi, W., \& Winanti, P. S. (2020). Tata Kelola Penanganan Covid-19 di Indonesia: Kajian Awal. D.I. Yogyakarta: Tata Kelola Penanganan Covid-19 di Indonesia: Kajian Awal. Retrieved Agustus 2020, from https://digitalpress.ugm.ac.id/book/257

[29] OECD. (2013). Government at Glance 2013. France: OECD. doi:10.1787/gov_glance-2013-en

[30] Olsson, A., \& Phelps, E. A. (2007). Social learning of fear. Nature Neuroscience, Vol. 10, 1095-1102. doi: $10.1038 / \mathrm{nn} 1968$.

[31] Pakpour, A. H., \& Griffiths, M. D. (2020). The fear of COVID-19 and its role in preventive behaviors. Journal of Concurrent Disorders.

[32] Shadiqi, A. M., Hariati, R., Hasan, K. F., I'anah, N., \& Istiqomah, W. A. (2020, Juni 12). Panic buying pada pandemi COVID-19: Telaah literatur dari perspektif psikologi. Jurnal Psikologi Sosial, 18(59), 1-12. doi:10.7454/jps. 2020.xx

[33] Shou, B., Xiong, H., \& Shen, Z. M. (2011). Consumer Panic Buying and Quota Policy under Supply Disruptions. Manufacturing \& Service Operations Management, 1-29. Retrieved from http://personal.cb.cityu.edu.hk/biyishou/files/MSOMPanic.pdf

[34] Sim, K., Chua, H. C., Vieta, E., \& Fernandez, G. (2020). The anatomy of panic buying related to the current COVID-19 pandemic. Psychiatry Research, Vol. 288. doi: 10.1016/j.psychres.2020.113015. 
[35] Sucahyo, N. (2020, Maret 20). Kelangkaan Alat Pelindung Diri Hambat Layanan Medis. Retrieved Juli 2020, from VOA Indonesia: https://www.voaindonesia.com/a/kelangkaan-alat-pelindung-dirihambat-layanan-medis-/5337744.html

[36] Sucahyo, N. (2020, April 8). Pemerintah Harus Perbaiki Komunikasi Publik Terkait Corona. Retrieved Juli 2020, from VOA Indonesia: https://www.voaindonesia.com/a/pemerintah-harusperbaiki-komunikasi-publik-terkait-corona/5364324.html

[37] Sugiyono. (2013). Metode Penelitian Kuantitatif, Kualitatif, \& RD. Bandung: CV. Alfabeta.

[38] Wahyudi, J., Milla, M. N., \& Muluk, H. (2017). Persepsi Keadilan Sosial dan Kepercayaan Interpersonal sebagai Prediktor Kepercayaan Politik pada Mahasiswa di Indonesia. Jurnal Psikologi Sosial, 15(1), 59-71. doi:10.7454/jps.2017.6

[39] Wijaya, T. (2020, may 18). Factor Analysis of Panic Buying During the Covid-19 Period in Indonesia. SSRN Electronic Journal, 1-13. doi:10.2139/ssrn.3603750

[40] World Health Organization. (2020, 9 Januari). WHO Statement regarding cluster of pneumonia cases in Wuhan, China. Dipetik Agustus 2020, dari WHO: https://www.who.int/china/news/detail/09-012020-who-statement-regarding-cluster-of-pneumonia-cases-in-wuhan-china

[41] Yuen, K. F., Wang, X., Ma, F., \& Li, K. X. (2020). The Psychological Causes of Panic Buying Following a Health Crisis. International Journal of Environmental Research and Public Health, 17(10), 1-14. doi:10.3390/ijerph17103513 